\title{
SAVING AMERICAN HISTORY
}

Cameron Zindars

Mahomet-Seymour High School

Mahomet, Illinois
Teaching History 46(2)

DOI: 10.33043/TH.46.2.49-52

(C) 2021 Zindars.

Distributed with CC BY-NC-ND 4.0 License.

There is a resurgence of national preoccupation over the content selection and methodology of what is taught to children in classrooms across America. Highly polarized citizens, politicians, and national media are in a war of words and hyperbolic rhetoric on the issue of how to teach the narrative of America. The classroom is often the battleground over the culture wars and is center stage of the infighting and identity politics in America. This emotionally charged issue is at the forefront of the American public as the pandemic and digital learning pried open the doors of classrooms, making educators' curriculum highly accessible. The additional controversy over critical race theory has increased the chaos and polarization of teacher content selection. What is often missed in the onslaught of public grandstanding over this issue is how this pressure affects the countless professional educators who are warily wading the waters of how they approach teaching history. History educators must bypass the societal pressures of how to teach American history and should instead help students critically analyze the nuances in America's narrative.

The debate over how American history should be taught has been raging for decades. In the early 20th century, the United Daughters of the Confederacy (UDC) had a profound impact on the way the American narrative was taught. The UDC was able to overhaul countless southern history curricula by writing their own history textbooks to combat those of the North. Believing that Northerners were peddling a false narrative of the Civil War, the intent of the UDC was simple: To challenge the falsities of the North and to uphold the legacy of the Confederacy and the "Lost Cause." The UDC was able to interject a strong pro-Southern narrative in the writing of many history textbooks and American literature for many decades in the United States. ${ }^{1}$

Controversy over the presentation of the American narrative continued in the 1920s-1940s as Harold Rugg, a professor at Columbia University's Teachers College, created a series of social studies textbooks. Rugg had become convinced that laissez-faire economic policies, geared towards unrestrained capitalism, were detrimental to American society and its democratic foundation. This belief influenced Rugg's textbooks as he reimagined social studies and the role of children in their learning. The intent of his curriculum was to empower students to think critically about problems in American society, encouraging them to question societal structures and to propose alternatives. While early opposition to his textbooks existed, dire concerns over the textbooks being "un-American" and "communist" developed as organizations like the American Federation of Advertising and American Legion began a crusade against Rugg. By labeling Rugg and his textbooks "un-American" and associating them with communism, the opposition proved successful. A drastic decline in the sale of his textbooks occurred in just a four-year span, mangling the dispersion of Rugg's legitimate criticisms. ${ }^{2}$

Similar to Rugg, the National Center for History in the Schools attempted to rethink American history learning and curriculum in the early 1990's. They created national history standards that would rely heavily on historical thinking skills, as well as contemporary historiography and scholarship. This panel consisted of a wide range of educators and scholars and, through unified consensus, created standards that broadened the focus of American history. Opposition to these standards developed immediately, with critics claiming that the standards were replacing traditional American history with negative anti-American history. As a result of the backlash from politicians, media, and conservative historians, the standards failed to pass on a national level. ${ }^{3}$

In 2014, the College Board made substantial changes to their Advanced Placement United States History curriculum and cumulative exam, coincidentally similar to those of NCHS. Once again, conservatives argued

\footnotetext{
${ }^{1}$ Arica L. Coleman, "The Civil War Never Stopped Being Fought in America's Classrooms. Here's Why That Matters," Time, November 13, 2017, https://time.com/5013943/john-kelly-civil-war-textbooks/

${ }^{2}$ Charles Dorn, “'Treason in the Textbooks': Reinterpreting the Harold Rugg Textbook Controversy in the Context of Wartime Schooling," Paedagogica Historica 44, no. 4 (2008): 457-479.

${ }^{3}$ Andrew Hartman, A War for the Soul of America: A History of the Culture Wars (Chicago, IL: University of Chicago Press, 2016).
} 
this revised curriculum portrayed American history from a cynical point of view and that it was preaching "identity politics." Conservatives demanded the College Board replace what they believed to be an unpatriotic narrative of American history, with a more palatable and optimistic version. Backlash won out, and conservatives were able to curtail the College Board curriculum. ${ }^{4}$

Transition to the fall of 2019, and the debate over the narrative of America continued with the release of the polarizing 1619 Project, published by the New York Times. The intent of this project was to provide a nontraditional argument that 1619, when the first enslaved people arrived in America, not 1776, and the signing of the Declaration of Independence, was the major starting point of American society. Nikole Hannah-Jones envisioned this project as a supplemental curriculum for teaching about slavery and its immediate and longterm impacts in American history. This project was perplexing to left leaning historians, as many appreciated the overall intent of the project, however, some questioned parts of the historical accuracies within the project. Princeton historian Sean Wilentz wrote a scathing letter in response to one of the central claims of the project, that the American Revolution was fought over the institution of slavery. In addition to Wilentz's criticism, a group of well-respected conservative and liberal historians such as Gordon Wood, James McPherson, and James Oakes joined in opposition to the project. Their intent was to refute problems they saw within the project and to encourage remedies to improve some of its historical flaws. ${ }^{5}$

Other critics, however, were much more scathing in their condemnation of the 1619 Project. Newt Gingrich referred to the project as a "lie." ${ }^{6}$ Similarly, former President Trump referred to the project as "completely discredited," and he insinuated it was revisionist history that overlooked America's history of freedom. ${ }^{7}$ Trump's disdain for the project went further, stating:

Critical race theory, the 1619 project [sic], and the crusade against American history is toxic propaganda, ideological poison that if not removed will dissolve the civic bonds that tie us together. It will destroy our country. That is why I recently banned trainings in this prejudiced ideology from the federal government and banned it in the strongest manner possible. ${ }^{8}$

In January 2021, in direct opposition to critical race theory (CRT) and the 1619 Project, Trump's administration pandered to conservatives by releasing the 1776 Report. This report addressed conservatives' growing concern with the unpatriotic telling of American history from liberals. Instead of focusing on a more critical and nuanced view of America history, the report hoped to redeem the traditional telling of American exceptionalism and patriotism. The intent of the report was to promote an American history narrative that was "accurate, honest, unifying, inspiring, and ennobling."

Amid the outcry against Black Lives Matter protests, the 1619 Project, and critical race theory, some politicians and state legislators have demanded these topics be banned from schools. ${ }^{10}$ Obsessive concern over concepts like CRT have permeated the American public, as seen by Fox News' mention of CRT over 1300 times in a span of four months. These preoccupations have found their way into school boards across America, as schools and states mandate bans against CRT. For example, over eight states have enacted legislation targeting CRT and

\footnotetext{
${ }^{4}$ Lindsey Layton, “Conservatives Convinced College Board to Rewrite American History,” Washington Post, June 30, 2015, https://www.washingtonpost.com/local/education/college-board-rewrites-american-history/2015/07/30/cadadd4c-36d1-11e5-b673-

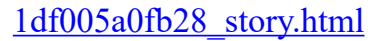

${ }^{5}$ Adam Serwer, "The Fight Over the 1619 Project Is Not About the Facts," The Atlantic, December 23, 2019, https:/www. theatlantic.com/ideas/archive/2019/12/historians-clash-1619-project/604093/

${ }^{6}$ Ibid.

${ }^{7}$ Brian Stelter and Oliver Darcy, "1619 Project Faces Renewed Criticism-This Time from within The New York Times," CNN, October 12, 2020, https://www.cnn.com/2020/10/12/media/new-york-times-1619-project-criticism/index.html

${ }^{8}$ Juan Perez, Jr. and Nicole Gaudiano, "Trump Blasts 1619 Project as DeVos Praises Alternative Black History Curriculum,"

Politico, September 17, 2020, https:/www.politico.com/news/2020/09/17/devos-black-history-1776-unites-417186

${ }^{9}$ The President's Advisory 1776 Commission, "The 1776 Report," 2021.

${ }^{10}$ Sarah Schwartz, “Lawmakers Push to Ban '1619 Project' From Schools,” Edweek, February 3, 2021.
} 
another twenty states have proposed legislation that would do something similar. ${ }^{11}$ Republican Tom Cotton of Arkansas proposed legislation hyperbolically called the "Saving American History Act of 2020." This bill proposed to defund any states that taught the indoctrinating "left-wing garbage" of the 1619 Project. ${ }^{12}$ Behind the scenes of the rhetoric, fear mongering, and debate over history curriculum are the teachers who inevitably feel pressure from both the left and the right to teach a particular way.

In 2021, the Thomas B. Fordham Institute released a nation-wide evaluation of individual state standards covering United States history and civics. The report stated the authors' desire to be bipartisan, and that they believe state standards should not succumb to the "whitewashing" of history or "obsessive wokeness." Further, in the introduction they acknowledged the deep-seated polarization of our country and that now more than ever, America needs high quality and robust state standards. The authors' evaluation was based on how well a state's standards clearly communicated specific information Americans should know, emphasized historical thinking skills, promoted civic engagement, and how well American history and civics are included in the K-12 curriculum. Overall, the evaluation found the majority of state standards were inadequate or mediocre in their quality. A common criticism of the inadequate state standards was that they were too broad, and that they omitted or minimized fundamental topics and or themes of American history and civics. ${ }^{13}$ However, determining what facts, events, people, or topics are emphasized or omitted is often hotly contested and at the center of current culture wars.

Some argue history educators should only teach the facts, while remaining apolitical and neutral in the presentation of those facts. The irony of the expectation for educators to teach "objective facts" is that the selection and delivery of facts has proven to be highly disputed, even amongst well-respected historians. By analyzing different historians' surveys of the narrative of American history, it is obvious how much variation there is in each of their stories. Howard Zinn, author of A People's History of the United States, argues that from its birth, America has been dictated by the callous wealthy elite who deftly appease the middle class and ravage everyone else. Zinn presented an unfamiliar and messier history of America, a history of the infallible and heroic common people who challenged the oppression of the ruthless and cunning Establishment. For instance, Zinn dedicates an entire chapter to Native Americans and spends a great deal of time including their voice in his narrative of America. ${ }^{14}$

In comparison, Wilfred McClay's, Land of Hope, endorsed by Trump's 1776 Report, attempts to provide an inspiring, hopeful, truthful, and compelling survey of the American narrative. In step with many American narratives, McClay continues to put a spotlight on commonly heard voices and perspectives of American history, but continuously neglects the voices of conflict and dissent. His book sheds light on the "good" of America and its leaders and suggests that most of American history, even the bad, was inevitable or even justifiable. For example, McClay brushes over the impact of Andrew Jackson's Trail of Tears and the totality of westward expansion on Natives Americans, rarely dissecting the horrors they encountered such as the Battle at Little Bighorn, the Wounded Knee Massacre, and many more. ${ }^{15}$

The Fordham Institute, which released the nation-wide evaluation of individual state history standards, stated, "We understand and agree that there is more than one way to tell the American story, but if we refuse to compromise, that story may not be told at all." ${ }^{16}$ Both Zinn and McClay's accounts of the American narrative fail

\footnotetext{
${ }^{11}$ Rashawn Ray and Alexandra Gibbons, “Why are States Banning Critical Race Theory,” Brookings, July 2021, https://www. brookings.edu/blog/fixgov/2021/07/02/why-are-states-banning-critical-race-theory/

${ }^{12}$ Saving American History Act of 2020, S. 4292, $116^{\text {th }}$ Congress. (2020), https://www.govtrack.us/congress/bills/116/s4292/ summary

${ }^{13}$ Jeremy A. Stern, Alison E. Brody, José A. Gregory, Stephen Griffith, and Jonathan Pulvers, The State of State Standards for Civics and U.S. History in 2021 (Washington D.C.: Thomas B. Fordham Institute, 2021) https://fordhaminstitute.org/national/research/ state-state-standards-civics-and-us-history-2021

${ }^{14}$ Howard Zinn, A People's History of the United States (New York: HarperCollins Publishers, 2015).

${ }^{15}$ Wilfred M. McClay, Land of Hope: An Invitation to the Great American Story (New York: Encounter Books, 2019).

${ }^{16}$ Stern, et al., The State of Standards for Civics and U.S History in 2021.
} 
to show history for what it often is: complex and nuanced. Maybe the compromise is finding a middle ground between Howard Zinn's fatalistic leftist history and Wilfred McClay's conservative and naive grand narrative of American exceptionalism. Or maybe another approach might be looking at the American narrative through a particular perspective. For example, in her book These Truths: A History of the United States, Harvard historian Jill Lepore elected to analyze whether America has lived up to the nation's founding principles in the Declaration of Independence and the Constitution. ${ }^{17}$

Regardless of the longstanding historical pressures to teach American history a particular way, history educators would be wise to learn from Harold Rugg's vision for his students. The demand for educators to cultivate responsible citizens and lifelong learners will never be met by teaching uninspired facts of an undisputed history. As Rugg suggested, history educators should empower students to critically analyze the nuance of history and to ultimately formulate their own evaluations of the past. The true spirit of a democratic society is to educate its citizens in a way in which they can use their voice to better society. Making our classrooms student-centered and spending ample time having students analyzing content using historical thinking skills such as change and continuity, argumentation, contextualization, inquiry, and research will empower them. Furthermore, ensuring our formative and summative assessments heavily rely on these skills provides students with the opportunity to demonstrate their thinking.

It is also important to identify key themes in American history, and to make those themes the lynchpin of the course. Teaching in this way helps to narrow the focus of the class and, like Lepore's text, provides a through-line for students to connect with during the school year. Then, while teaching about these themes, we should ensure that students are provided multiple perspectives on the themes, especially through the use of primary sources. For example, in his book The Story of American Freedom, historian Eric Foner provides an analytical overview of American history through the lens of freedom. Foner goes to great lengths to argue that as some groups gain freedom, inevitably other groups are consequently denied freedom. For example, as the Constitution was being debated, the Framers protected the freedom of whites to own and enslave other people, thus stripping African Americans of their freedoms. ${ }^{18}$

In addition to using themes in American history, educators should choose to use powerful content that they are passionate about to help teach these themes. Students feed off of our energy as teachers, for better or for worse. The commonly encouraged apolitical, neutral, and apathetic educator crushes students' curiosity. Instead, as educators we should embrace both our own passions and our students' passions in order to cultivate a curiosity for learning. Oftentimes the best way to instill passion and curiosity is to choose topics of controversy and nuance and to permit students to research, discuss, and deliberate over them. Moreover, we must ensure that the content we teach is robust and that it includes an array of perspectives, and we must especially take time to provide a voice to the voiceless in traditional narratives of American history. We must know our students, meet students where they are, and identify their prior knowledge and skills. Sometimes that means the best thing for students is to encourage them to grapple with perspectives different than their own, or even those of society's prevailing view.

American history is messy, and the debate over how to teach it will likely continue. It is incredibly difficult to avoid being influenced by societal pressures of how to teach American history. However, it is imperative that history educators resist the pressures of society and instead uphold truly democratic principles in our classrooms. Educators should ensure our classrooms are founded on critical analysis and a nuanced telling of American history. This can be done by using central themes in American history as a through-line for students, while also allowing our passion and that of our students to cultivate a classroom culture of a curiosity for learning. Ultimately, our democracy is enhanced when we empower our students and help them hone the skills necessary to actively partake in critiquing and improving our country.

\footnotetext{
${ }^{17}$ Jill Lepore, These Truths: A History of the United States (New York: W. W. Norton \& Company, 2018).

${ }^{18}$ Eric Foner, The Story of American Freedom (New York, New York, W. W. Norton \& Company, 1998).
} 